\title{
PROPERTY VALUE ASSESSMENT GROWTH LIMITS AND REDISTRIBUTION OF PROPERTY TAX PAYMENTS: EVIDENCE FROM MICHIGAN
}

\author{
Mark Skidmore, Charles L. Ballard and Timothy R. Hodge
}

\begin{abstract}
We examine the change in the distribution of property tax payments resulting from Michigan's imposition of a property tax assessment growth cap in 1994. The cap restricts growth in property value for tax purposes to the inflation rate, for those maintaining continuous ownership. Upon sale, however, the tax base is adjusted to reflect market value. Using data from a survey conducted in 2008, we find that long-time homeowners enjoy an average reduction in effective tax rates (relative to new homeowners) of 19 percent. The cap also appears to have reduced effective property tax rates for older homeowners, and for those with higher incomes.
\end{abstract}

Keywords: property tax, incidence, assessment growth limit

JEL Codes: H71, H22

\section{INTRODUCTION}

ccording to Haveman and Sexton (2008), at least 20 states now have some sort of limitation on the rate at which property tax assessments are allowed to grow over time. ${ }^{1}$ Michigan's assessment growth cap was part of Proposal A, a sweeping education finance reform that was approved by referendum in $1994 .^{2}$ Proposal A included major

\footnotetext{
${ }^{1}$ Such limitations have been referred to as "assessment growth caps," "taxable value caps," "assessment growth limits," and "property value assessment limits." These terms are used interchangeably in this article. Maryland was the first state to impose a limit on assessment increases, in 1957. California and Iowa introduced assessment growth limits in 1978, and New Mexico, Arizona, and New York followed soon after (United States Advisory Commission on Intergovernmental Relations, 1995).

${ }^{2}$ For an extensive discussion of Proposal A, see Feldman, Drake, and Courant (2003).
}

Mark Skidmore: Department of Agriculture, Food, and Resource Economics and Department of Economics, Michigan State University, East Lansing, MI, USA (mskidmor@msu.edu)

Charles Ballard: Department of Economics, Michigan State University, East Lansing, MI, USA (ballard@ msu.edu)

Timothy R. Hodge: Department of Agriculture, Food, and Resource Economics, Michigan State University, East Lansing, MI, USA (hodgetim@msu.edu) 
changes to many aspects of the public finances in Michigan. In this article, however, we are primarily concerned with the assessment growth cap.

Prior to the passage of Proposal A, property taxes were based on the "state equalized value" of a property (SEV). ${ }^{3}$ After 1994, the growth of residential property values for tax purposes was limited to the lesser of the general rate of inflation (as measured by the national Consumer Price Index) or 5 percent, regardless of the actual increase in $\mathrm{SEV}^{4}$ Thus, over time, the taxable value (TV) of a property could fall well below the SEV. However, Proposal A also specifies that the taxable value of a property is returned to the current market-based SEV when the property is sold. ${ }^{5}$ Therefore, in areas with significant increases in property values, the effective property tax rates facing long-time property owners have decreased, relative to those of more recent purchasers of property.

Our objective is to determine the extent to which the taxable value cap has redistributed tax payments across economic and demographic groups. We examine the distributional consequences of the taxable value cap, using detailed data on property tax payments and housing values, obtained through a survey taken in the winter of 2008.

In the next section, we briefly describe property tax policy in Michigan. In Section III, we review earlier research regarding property value assessment growth limits. The empirical strategy for measuring the determinants of tax payments is described in Section IV. In Section V, we describe the data and discuss some additional econometric issues. The estimation results are presented in Section VI, and Section VII is a brief conclusion.

\section{THE PROPERTY TAX IN MICHIGAN}

Prior to 1994, property taxation in Michigan had two key characteristics. First, public schools were financed almost exclusively through local property taxes. Since there was wide variation among school districts in the value of taxable property per student, this decentralized fiscal system led to extreme differences among school districts in expenditure per student. Second, the overall level of property taxation was well above the national average. ${ }^{6}$ These features were the source of considerable dissatisfaction among

\footnotetext{
${ }^{3}$ The SEV is 50 percent of the assessed market value of the property. Each year, the assessor in each jurisdiction in Michigan determines the SEV of each property in the jurisdiction, as of December 31 of the previous year.

${ }^{4}$ The 5 percent limitation has not had any practical effect, since the general inflation rate has been lower than 5 percent throughout this entire period.

${ }^{5}$ This "pop up" also occurs in the case of a property transfer that does not involve an explicit sale of the property. For example, property ownership may be transferred from one family member to another, but the tax benefits cannot be transferred to the new owner.

${ }^{6}$ Data from the U.S. Census Bureau for state and local government finances are available online at http:// www.census.gov/govs/www/estimate.html. Before Proposal A, property taxes typically accounted for about 41 percent of state and local tax revenues in Michigan. This was well above the national average of about 30 percent. After Proposal A, property taxes have accounted for about 38 percent of Michigan revenues, which is closer to the national average, which remains around 30 percent. Michigan's property taxes remained above the national average when measured on a per-capita basis, but the difference between Michigan and the U.S. average was reduced. However, it should also be noted that, throughout
} 
voters, and they led to a long series of reform measures. These policies are discussed in detail in Feldman, Courant, and Drake (2003).

Along with the taxable value cap, Proposal A also introduced a distinction between "homestead property" and "non-homestead property," where the homestead is defined as the homeowner's principal residence. For homestead property, Proposal A imposed a maximum on the statutory property tax millage rate ${ }^{7}$ that local school districts could use for public school operating expenses. This is known as the "homestead exemption," since it does not apply to non-homestead property. As a result of the homestead exemption, average statutory millage rates were reduced by about one-third. ${ }^{8}$ The state government then added a 6-mill "state education tax," and increased sales taxes and cigarette taxes to provide for the financing of elementary and secondary public education. ${ }^{9}$

In Table 1, we present statewide average statutory property tax millage rates from 1990 through 2008. Over this period, the only major shift in average statutory millages occurred in 1994 with the passage of Proposal A. However, the averages reported in Table 1 should not obscure the fact that there is substantial variation. As mentioned above, statutory property tax rates vary a great deal from one jurisdiction to another (both before and after Proposal A). Also, as a result of the taxable value cap, Proposal A led to within-jurisdiction differences in effective property tax rates. These withinjurisdiction differences did not exist before Proposal A.

this period, Michigan also provided an income-based circuit breaker. The circuit breaker, known as the "Homestead Property Tax Credit," operated as a refundable credit in the state's income tax. Thus, if the Homestead Property Tax Credit is netted out, the burden of the property tax in Michigan is reduced. In fact, the Homestead Credit is more generous to senior citizens than to others, and if we combine this with Michigan's generous treatment of pension income which is generally not taxed, elderly Michigan residents have a negative effective rate of income taxation. While the focus of this article is on property taxes themselves, we conduct additional analysis to determine whether taking into account the Homestead Property Tax Credit makes any difference to our core findings. As described later, our findings are robust to this consideration.

${ }^{7}$ One mill is defined as $\$ 1$ per $\$ 1,000$ of taxable value.

${ }^{8}$ The homestead exemption effectively equalized the statutory property tax millage rates for local school operating expenses on homestead properties across the state. This reduced the disparities in overall statutory millage rates across jurisdictions, but it did not eliminate them. Substantial differences in overall millage rates remain, as a result of differences in millage rates between homestead and non-homestead properties, and as a result of differences in the millage rates for school capital expenditures, and for municipal governments, county governments, and special districts.

${ }^{9}$ Proposal A also put severe restrictions on the ability of local units to increase property taxes on their own. Thus, the financing of operating expenses for K-12 public education became much more centralized than it had previously been. Also, the funding formulas pushed in the direction of more equal per-student funding for operating expenses, although considerable gaps remain between the highest- and lowest-spending districts. Per-pupil spending increased substantially in many of the poorest districts, as increased state aid outweighed the reduction in property tax revenues. Spending increases were more modest, or even negative, for more affluent districts. For further discussion of these changes, see Arsen and Plank (2003) and Papke (2008). See Papke $(2005,2008)$ for an excellent analysis of the effects of school finance reform on educational outcomes. In the area of school capital expenses, local school districts still must rely on their own property taxes. As a result, funding disparities for school capital expenses are much larger than those for operating expenses. For discussion, see Arsen, et al. (2005). 


\section{Table 1}

Statewide Average Property tax Millage Rates in Michigan, 1990-2008

\begin{tabular}{lccc}
\hline Calendar Year & Homestead Property & Nonhomestead Property & All Property \\
\hline 1990 & 57.17 & 57.17 & 57.17 \\
1991 & 57.34 & 57.34 & 57.34 \\
1992 & 58.09 & 58.09 & 58.09 \\
1993 & 56.64 & 56.64 & 56.64 \\
1994 & 30.22 & 48.17 & 38.19 \\
1995 & 31.00 & 48.79 & 38.88 \\
1996 & 31.36 & 49.54 & 39.32 \\
1997 & 31.36 & 49.63 & 39.25 \\
1998 & 31.43 & 49.68 & 39.27 \\
1999 & 31.40 & 49.76 & 39.16 \\
2000 & 31.54 & 50.10 & 39.32 \\
2001 & 32.12 & 50.72 & 39.78 \\
2002 & 32.60 & 51.00 & 40.17 \\
2003 & 31.52 & 50.06 & 39.00 \\
2004 & 32.70 & 51.20 & 40.00 \\
2005 & 32.60 & 51.38 & 39.88 \\
2006 & 32.65 & 50.96 & 39.96 \\
2007 & 32.72 & 51.49 & 39.89 \\
2008 & n.a. & n.a. & 38.94 \\
\hline
\end{tabular}

Sources: All millage rates from State Tax Commission except 1994; millage rates for 1994 from the Tax Analysis Division, Michigan Department of Treasury, http://www.michigan.gov/ taxes/0,1607,7-238-43551_44149---,00.html.

It is important to note that Proposal A was not the first mechanism for restraining property tax revenues in Michigan. Prior to Proposal A, property tax revenues were already limited by the "Headlee Amendment," which was passed in $1978 .{ }^{10}$ While Proposal A limits statutory millage rates and imposes a limit on the growth in taxable values, the Headlee Amendment puts a direct limitation on property tax revenues. The Headlee Amendment restricts property tax revenue growth to the rate of inflation (with an adjustment for new construction). Any jurisdiction with potential revenue increases exceeding the Headlee limit is required to reduce property tax rates, in order to bring revenues into line with the revenue-growth restriction. This type of tax-rate reduction is known as a "Headlee rollback." 11 Prior to the introduction of the taxable value cap, rapidly rising property values resulted in numerous Headlee rollbacks.

10 The Headlee Amendment is named for its author, Richard H. Headlee.

${ }^{11}$ Local residents can choose to exceed the Headlee limitation by referendum, but this occurrence is relatively uncommon. Note that the taxable value cap can interact with Headlee rollbacks. To the extent that the cap puts a jurisdiction under the Headlee limit in a given year, the new Headlee limit is computed from the lower base (Feldman, Courant, and Drake, 2003). 
After Proposal A, however, rollbacks were greatly reduced, both in number and in magnitude.

Thus, before Proposal A, the Headlee Amendment provided a mechanism for limiting property tax rates, in a uniform manner across all properties in a jurisdiction. Proposal A effectively instituted a new system for limiting effective property tax rates, but the Proposal A mechanism did not treat all properties in a jurisdiction uniformly. Instead, under Proposal A, the taxable value cap reduced effective tax rates for existing homeowners, but not for new homebuyers.

The Michigan Department of Treasury (2010) provides annual estimates of tax expenditures for all major sources of tax revenue. In the 2010 fiscal year, the estimated revenue loss from the taxable value cap was $\$ 3.4$ billion, which is second only to the homestead exemption, which produced an estimated revenue loss of $\$ 3.52$ billion. These two property tax expenditures are estimated to make up more than two-thirds of the total tax expenditures associated with the property tax. The tax expenditure associated with the taxable value cap is sufficiently large that, if it had been removed, holding total property tax revenues constant, the statewide average statutory tax rate could have been reduced by about 20 percent in 2008 (the year of the survey). ${ }^{12}$ In some counties, the average statutory tax rate could have been reduced by more than 40 percent. ${ }^{13}$ Thus, tax base erosion has occurred unevenly across the state and across individual properties, and this has led to significant horizontal inequities among property owners.

From 1994 through 2005, average housing values grew faster than the general price level. Thus, for long-time homeowners, on average, taxable value fell further and further below state equalized value until 2005. However, average housing prices in Michigan increased at a rate below the rate of inflation in 2005. Beginning in 2006, average housing prices began to fall. Because of this reversal in the relationship between the change in housing prices and the change in the overall price level, the gap between taxable value and state equalized value has diminished in recent years.

\section{THE LITERATURE ON PROPERTY TAX LIMITATIONS}

Early empirical research on property tax limits, including property value assessment growth constraints (such as Dye, McGuire, and McMillen (2005), Mullins and Joyce (1996), and Skidmore (1999)), tended to focus on determining the degree to which these emerging fiscal institutions constrained the growth of property tax revenue. More recently, researchers have focused their attention on the distributional consequences of

12 This calculation is based on data for taxable value and state equalized value as of 2008 . However, it should be noted that falling home values have reduced the gap between taxable value and state equalized value over the past two to three years. By 2009, if state equalized value had been taxed fully, the statewide average statutory rate could have been reduced by 15 percent.

${ }^{13}$ Four counties (Antrim, Benzie, Cheboygan, and Keweenaw) had taxable values that were less than 60 percent of state equalized value, on average. Five counties (Bay, Dickinson, Kent, Midland, and Saginaw) had taxable values that exceeded 85 percent of state equalized value, on average. For each of the remaining 74 counties in Michigan, the ratio of taxable value to state equalized value, on average, was between 0.61 and 0.85 . 
assessment growth caps, and we focus on this research here. Dye, McMillen, and Merriman (2006) consider the assessment growth cap introduced in Cook County, Illinois, in 2004. They demonstrate that a taxable value cap for residential owners (as in Cook County) will necessarily lead to increased taxes for industrial and commercial property owners, if property tax revenues are to be maintained. Generally, whenever an effective tax rate reduction is given to one type of property, if a revenue goal is to be achieved, either other types of property must have an increased rate, or there must be an increase in some other revenue source.

The Minnesota Department of Revenue (2007) reports that, as a result of a taxable value cap, 84 percent of residential homesteads in Minnesota had to pay a higher tax in 2006 than they would have had if taxable values had remained unrestricted, all else equal. Muhammad (2007) discusses the substantial horizontal inequities that have resulted from the taxable value cap in the District of Columbia.

Mikesell and Mullins (2008) examine the determinants of residential tax payments, using household-level data from the Public Use Micro Samples of the 2000 Census of Population and Housing, along with subsequent Annual Community Surveys from the Bureau of the Census, from 2000 through 2006. They find that a range of policies, institutions, and household characteristics are correlated with household tax payments. From the perspective of the present study, it is most important to note that Mikesell and Mullins find that tenure in a home is negatively correlated with tax payments as a proportion of income.

In addition to reducing tax revenues and creating horizontal inequities, the taxable value cap could create a "lock-in effect." In the words of Dye, McMillen, and Merriman (2006), the tax cap "may discourage mobility, since the expanded exemption is lost when real estate is sold, and, thus, may decrease the efficiency of the residential real estate market." Several studies examine the effect of property tax caps on household mobility. Wasi and White (2005) examine the potential lock-in effect for housing choice from California's Proposition 13 (enacted in 1978), using data from 1970 to 2000 . They find a significant effect: the average tenure length of California homeowners increased by 0.66 years, or 6 percent, relative to homeowners in Texas and Florida, which were chosen as comparison states. The increase was as high as two or three years in places like San Francisco and San Jose, where long-time homeowners received the largest tax reductions from the assessment growth limit.

Ferreira (2004) also examines residential mobility in California after Proposition 13 , but he focuses on the two amendments that allow for transferability of the implicit tax benefits to a new home for heads of household aged 55 or older. Ferreira finds that mobility for the 55 -year-old group is about 25 percent higher than mobility for the 54-year-old group. ${ }^{14}$

To our knowledge, previous studies have not explicitly examined the degree to which assessment growth caps have altered tax payments across economic and demographic

\footnotetext{
${ }^{14}$ Nagy (1997) also examines the change in household mobility after California's Proposition 13, using the Annual Housing Surveys from 1975, 1978, and 1982. He finds evidence of a decline in mobility, but the decline is not significantly different from similar declines in other parts of the country. For other recent work on the consequences of property value assessment growth limits, see Anderson and McGuire (2007), Bowman (2006), Giertz (2006), Ihlanfeldt (forthcoming) and Youngman (2007).
} 
groups. Since length of tenure in a home depends on income, age, and other demographic characteristics, an assessment growth cap may redistribute property tax payments across economic and demographic groups. The primary motivation for this article is to increase our understanding of this redistribution of property tax payments.

A potentially confounding issue for our analysis is that assessment growth caps may have an effect on property values. In other words, the differences in tax payments associated with the taxable value cap may be capitalized into home values, thus altering effective property tax rates. Indeed, Guilfoyle (1998) finds that a portion of the initial tax benefits of Michigan's Proposal A was capitalized into home values. ${ }^{15}$ However, it should be noted that Guilfoyle's analysis deals with the period immediately before and after enactment of Proposal A, during which virtually all Michigan homeowners saw substantial decreases in property taxes. ${ }^{16}$

The effect of the taxable value cap on property values is indeterminate, because (all else equal) it leads to higher property taxes for some, and lower taxes for others. For homebuyers who expect to remain in their homes for many years to come, and who expect home values to rise more rapidly than the Consumer Price Index, the taxable value cap may represent a potential long-run benefit. ${ }^{17}$ For homeowners in this situation, lower future tax payments for the duration of tenure in the home may lead to higher willingness to pay. However, for those who expect to move from one home to a different home in the state in the near future, the taxable value growth cap can impose higher effective property tax rates. These homebuyers may have reduced willingness to pay for a home, as a result of the taxable value growth cap. In addition, if mobility is reduced because of the taxable value growth cap, fewer homes may be available on the market, and this may lead to higher housing prices, all else equal. ${ }^{18}$ Further, because of the Headlee Amendment (the property tax revenue growth limit), average tax burdens

${ }^{15}$ In addition to Guilfoyle (1998), see Oates (1969), Wales and Wiens (1974), King (1977), Reinhard (1981), Richardson and Thalheimer (1981), Rosen (1982), and Palmon and Smith (1998) for excellent discussions of the property tax capitalization issue.

${ }^{16}$ Guilfoyle identifies the parameters of his model using the large variation in the relative size of the tax reductions brought about by Proposal A.

${ }^{17}$ Home values have fallen recently. As long as taxable value is less than state equalized value, taxable value is allowed by law to increase by the rate of inflation, even when state equalized value is declining. Thus, in the last few years, many Michigan homeowners have experienced the odd combination of falling home values and rising property tax bills. However, for properties where state equalized value no longer exceeds taxable value, the taxable value will fall with state equalized value. This can occur for long-time homeowners if the drop in value is sufficiently large (as in the case of one of the authors of this article). It can also occur for homeowners who bought a home at or after the peak of prices in the middle of the first decade of the $21^{\text {st }}$ century (as in the case of another of the authors of this article). In the public discussion leading up to Proposal A, little or no attention was focused on the possibility that home values could ever see a widespread decline. Recently, the combination of falling property values and rising tax payments has been the cause of much public outcry. In response, state legislators have considered proposals to prevent increases in property tax payments in an environment of falling home values. In the recent public debate, relatively little attention has been given to the fact that many of the affected homeowners have received substantial tax reductions from the taxable value cap over the years.

${ }^{18}$ It is also possible that the reduced number of homes on the market could be offset by a reduction in the number of buyers. 
in any given community might not have been substantially different than they currently are, even if the taxable value cap had never been imposed. ${ }^{19}$

A general framework for evaluating the effects of property taxes on property values was set out by Yinger (1982) and Yinger, et al. (1988). Based on this earlier work, we define a capitalization equation, which is derived from a utility maximization model:

$$
V=\sum_{n=1}^{N} \frac{R}{(1+i)^{n}}-\sum_{n=1}^{N} \frac{\beta T P}{(1+i)^{n}}
$$

Equation (1) shows that the value of a home, $V$, is equal to the net present value of the stream of rental services it generates, $R$, minus the net present value of the stream of tax payments, $T P$, where $i$ is the real discount rate and $N$ is the useful life of the home. The annual rental price of a property, $R$, is a function of the characteristics of the property and community; we assume that these characteristics are constant over time. Finally, $\beta$ is a parameter ranging between $0-1$, which defines the degree to which the stream of tax payments is capitalized into the value of a property.

Evaluation of the taxable value cap requires a modification of (1), because $T P$ depends on the general rate of increase (or decrease) in property values, the date of purchase, and the length of time the owner plans to own the property. With these modifications, we have calculated the present value of a home $(V)$ in the Headlee environment and in the Proposal A environment. We assume that the life of a home $(N)$ is 40 years, and the discount rate $(i)$ is 0.05 . The tax payment under the Headlee regime is assumed to be a constant proportion of the rental value. ${ }^{20}$ We further assume that under Proposal A, when the property is sold or transferred, the tax payments increase by 1.43 percent times the number of years of ownership (as per our estimates), and we assume that the average length of tenure in the home is 16 years (as per our survey data). Finally, we assume that the capitalization rate $(\beta)$ is 1 , so that our calculations should be seen as an upper bound.

Our calculations (the details of which are available on request) suggest that property values are not very sensitive to these assumptions, and that property values are very similar under the two scenarios. Generally, the effect of the changing property tax environment on property values is ambiguous: It depends on expectations about future home prices, the rate of inflation, and home tenure length. Given the data from the survey and the Michigan experience, these initial explorations suggest that the taxable value cap probably has not altered home values in a substantial way.

${ }^{19}$ The Headlee revenue growth limitation requires rate rollbacks whenever revenue growth exceeds the rate of inflation plus new construction. In the absence of the taxable value cap, Michigan communities would have experienced more rate rollbacks, which would have been uniform across all homeowners in a jurisdiction. With the taxable value cap, long-time owners emerge with lower effective property tax rates, at the expense of higher effective rates for newer homeowners.

${ }^{20}$ We also considered a scenario in which millages increase over time due to referenda. Specifically, voters may approve a Headlee override (as previously discussed) or they may approve a millage increase for other purposes. As of 2008, these extra voted millages were 37 percent of standard millages, on average. This alternative scenario yielded very similar capitalization rates. 


\section{EFFECTIVE TAX RATES AND TAX PAYMENTS}

As previously discussed, prior to the passage of Michigan's assessment growth limit in 1994, the taxable value for each property was its state equalized value (SEV), where the SEV is equal to one-half of the assessed market value. ${ }^{21}$ From 1995 on, the growth of taxable value for any property that is not sold during the period cannot exceed the rate of inflation, as measured by the national Consumer Price Index. If a property is sold, the taxable value returns to SEV. Thus, the effective property tax rate for homestead $i$ (EFFECTIVE RATE $)$ is given by

(2) EFFECTIVE RATE ${ }_{i}=\left(T P_{i} / V_{i}\right)=\mathrm{f}\left(T_{i}, C_{i}\right)$.

Equation (2) indicates that the effective property tax rate for homestead $i$ depends on the tax payment $\left(T P_{i}\right)$ and the market value of the home $\left(V_{i}\right)$, which in turn depend on community characteristics $\left(C_{i}\right)^{22}$ and the homeowner's length of tenure in the home $\left(T_{i}\right) .{ }^{23}$ As long as housing values rise at a rate faster than inflation, long-time homeowners will enjoy a tax benefit over new homeowners, and the magnitude of the benefit will increase over time.

This discussion illustrates the way in which differences in property tax payments and effective tax rates can emerge as a result of the interaction between changing home prices and the taxable value cap. In the next two sections, we present our empirical analysis of the property tax differentials that have emerged as a result of the taxable value cap.

${ }^{21}$ If the assessment is correct, then the SEV is equal to one-half of the true market value. Of course, assessments are not necessarily completely accurate. If a taxpayer believes that his/her property has been overassessed, the taxpayer can appeal, and these appeals are sometimes successful in reducing the assessment. On the other hand, some taxpayers may not be able to detect an inaccurate assessment, because of lack of information about market conditions, or they may be deterred by the transactions costs associated with the appeals process. In addition, taxpayers who believe their properties have been under-assessed do not typically appeal.

${ }^{22}$ There may be variations in community characteristics within a given jurisdiction. Because of data limitations, we abstract from these variations, and assume that everyone within a given jurisdiction has the same community characteristics.

${ }^{23}$ The tax payment portion of (2) for homestead $i\left(T P_{i}\right)$ is found by multiplying the taxable value of the property by the statutory tax rate. The taxable value of a property depends on (a) the value of that property at the time the property was last purchased, (b) the rate of inflation (as measured by the national CPI) over the period of ownership, and (c) the length of time the property has been owned since passage of Proposal A $\left(T_{i}\right)$. The statutory tax rate depends on the specific economic and demographic characteristics of the community in which the respondent lives. Therefore, the tax payment for homestead $i$ depends on (a) the value of the home at the time of last purchase, (b) the rate of inflation over the period of ownership, (c) the length of time the homeowner has owned the home since Proposal A $\left(T_{i}\right)$, and (d) the set of community-specific characteristics $\left(C_{i}\right)$ that determine statutory tax rates. In our analysis, the variable $T_{i}$ is truncated to a maximum, given by the number of years since the enactment of Proposal A. Since Proposal A was enacted in 1994 and our data are from 2007, the maximum value for $T_{i}$ is 13. 


\section{DATA AND ECONOMETRIC ISSUES}

In order to conduct this analysis, we must match information on homeowner economic and demographic characteristics with the characteristics of the communities in which they live. To accomplish this, we added several questions about property tax payments and home values to the State of the State Survey for winter $2008 .{ }^{24}$ The questions regarding 2007 property tax payments and home values were modeled after similar questions in the 2000 Census of Population and Housing.

This survey resulted in completed interviews with 1012 Michigan adults. However, 230 of the survey respondents were not homeowners. An additional 291 respondents failed to answer some of the questions needed for our regression analysis, including one or more of the questions on property taxes, home values, years of ownership, or other important variables. Finally, an additional 37 respondents were excluded from the analysis because they provided inconsistent information about age and homeownership. ${ }^{25}$

Summary statistics for the variables used in this analysis are presented in Table 2, and detailed definitions of all variables used in the analysis are shown in Appendix A. Table 2 includes summary statistics for the entire sample, as well as for three sub-groups, based on the rates of population growth for the counties in which the respondents reside. These categories split the full sample roughly into thirds. ${ }^{26}$ We expect respondents who live in areas with higher population growth to experience the largest effective tax-rate differentials between long-time homeowners and new homeowners.

From Table 2, the average effective property tax rate is 27 mills, but there are differences across sub-samples. ${ }^{27}$ Respondents in slow-growth areas have an average effective tax rate of about 30 mills, whereas the mean effective tax rate for respondents in high-growth areas is about 25 mills. Note also that slow-growth areas have substantially lower per-capita property values (measured by the WEALTH variable), and that jurisdictions with higher populations are likely to be located in slow-growth counties.

${ }^{24}$ The State of the State Survey (SOSS) is a quarterly telephone interview survey of Michigan adults, conducted by the Institute for Public Policy and Social Research, in the College of Social Science at Michigan State University. More information on SOSS is available at http://www.ippsr.msu.edu/SOSS. The winter 2008 survey, which is the $47^{\text {th }}$ round of SOSS, contains information from a stratified random sample of Michigan adults. The weighted sample is representative of the Michigan adult population. All of the statistical analyses reported in this article use the appropriate survey weights. The codebook and methodological report from the winter $2008 \mathrm{SOSS}$ are available at http://www.ippsr.msu/SOSS/SOSSdata.htm.

${ }^{25}$ For example, if a respondent says that he/she is 30 years old, and that he/she has owned the home for 20 years, this person would have been only 10 years of age at the time of becoming a homeowner. However, we also check for robustness with respect to the decision to exclude these 37 observations. We note that the inclusion of these observations results in similar estimates. In fact, the absolute magnitude of the coefficient on years of ownership increases slightly when these 37 observations are included. Thus, the regressions we present are the more conservative estimates.

${ }^{26}$ Appendix A provides the detailed definitions of counties with slow, medium, and high rates of population growth. Another Appendix (available upon request) lists the counties that fall into these three categories.

${ }^{27}$ As expected, the average effective property tax rate (shown in Table 2) is somewhat smaller than the average statutory tax rate (shown in Table 1). This is consistent with the erosion of the property tax base as a result of the taxable value cap. 


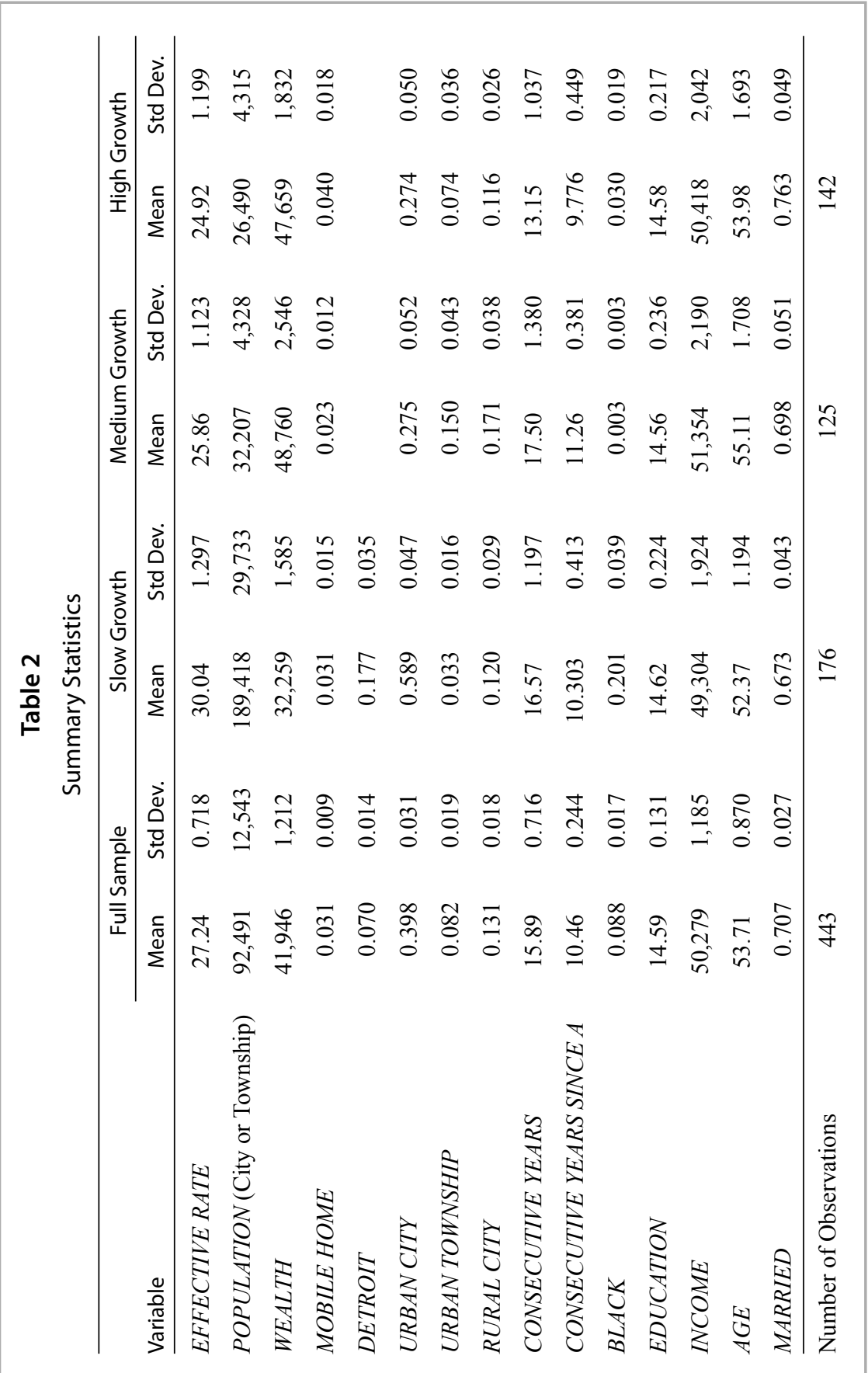


One possible strategy would be to estimate property tax outcomes as a function of individual and community characteristics, using ordinary least squares for the sample of homeowners who answered all of the relevant survey questions. The basic ordinary least squares regressions are represented by (3) and (4) below. Consider (3)

$$
\text { EFFECTIVE RATE } E_{i}=C_{i} \alpha+\delta T_{i}+\varepsilon_{i}
$$

where $E F F E C T I V E R A T E_{i}$ is the effective property tax rate, $C_{i}$ is a vector of community and individual characteristics, $T_{i}$ is the length of time that the homeowner $i$ has owned his or her property since the passage of Proposal A, and $\varepsilon_{i}$ is the error term. Below, we will refer to the total length of homeownership as CONSECUTIVE YEARS, and we will refer to the number of years of ownership since the passage of Proposal A as CONSECUTIVE YEARS SINCE A.

In (3), the length of homeownership since Proposal A(CONSECUTIVE YEARS SINCE $A$ ) enters the regression directly. However, the length of homeownership is determined, in part, by the economic and demographic characteristics of the homeowner. In a further attempt to analyze the underlying determinants of effective property tax rates, we replace $T_{i}$ (on the right-hand side of (3)) with a vector of respondent economic and demographic characteristics. Equation (4) represents our second set of property tax regressions:

$$
\text { EFFECTIVE RATE }{ }_{i}=C_{i} \eta+Z_{i} \lambda+\gamma_{i}
$$

where $C_{i}$ is a vector of community and individual characteristics, $Z_{i}$ is a vector of economic and demographic characteristics of the respondent, and $\gamma_{i}$ is the error term.

In all of the results reported below, these OLS estimates are reported first. However, since so many homeowners failed to answer questions about property taxes and home values, there is potential for sample-selection bias. To correct for possible selection bias, we use the procedure proposed by Heckman (1979) ${ }^{28}$ In this context, before estimating (3) and (4), it is necessary to estimate a first-stage selection regression. The selection equation is represented by:

$$
Y_{i}= \begin{cases}1 & \text { if } c_{i} \alpha+X_{i} \beta+u_{i} \geq 0 \\ 0 & \text { if } C_{i} \alpha+X_{i} \beta+u_{i}<0\end{cases}
$$

where $Y_{i}$ indicates whether the respondent provided information on all of the relevant questions, $C_{i}$ is a vector of community and individual characteristics, and $X_{i}$ is a vector of variable(s) that are excluded from the second-stage outcome equations ((3) or (4)). The variable(s) in $X$ are used to predict whether respondents report all of the relevant information. Specifically, in the estimates presented, we use educational attainment $(E D U C A T I O N)$ as an instrument. ${ }^{29}$ Appendix B reports the selection equation estimates,

${ }^{28}$ See Achen (1986) and Sigelman and Zeng (1999) for good theoretical and intuitive discussions regarding the Heckman procedure.

${ }^{29}$ EDUCATION is the number of years of schooling. In regressions not reported, BLACK is also included in the $X$ vector, but those results are not notably different than those reported here. 
showing that educational attainment is a good predictor of whether a respondent reports his or her tax payment and home value.

Selection bias is potentially present, although the direction of bias that might be introduced in the context of this analysis is not clear. Generally, we find little evidence of selection bias in the regressions for effective property tax rates. As a result, the OLS coefficients are very similar to the coefficients that control for selection bias. For thoroughness, we present results for the OLS regressions and for the regressions that address sample-selection bias. In the regressions that correct for sample-selection bias, we estimate the selection and outcome equations jointly by maximum likelihood.

In estimating (3) and (4), whether by OLS or the sample-selection procedure, we control for a range of individual and community characteristics. These include the population of the community (POPULATION), the wealth of the community, measured as per-capita state equalized value $(W E A L T H)$, whether the participant lives in the largest city in the state (DETROIT),$^{30}$ and whether the participant lives in an urban city, urban township, rural city, or rural township (URBAN CITY, URBAN TOWNSHIP, and RURAL CITY, respectively, with the excluded category being those who live in a rural township). ${ }^{31}$ We expect that those living in urban areas and in cities may face higher statutory rates, all else equal, because these jurisdictions have greater taxing authority and may offer a wider range of public services, including services directed at low-income populations. It is interesting to note that 8.2 percent of the residents in our sample live in urban townships, and 13.1 percent live in rural cities (see Table 2). Because properties located in mobile-home parks are exempt from the property tax in Michigan, we also include an indicator variable (MOBILE HOME) to control for whether the respondent lives in a mobile-home park.

Before discussing the regression results, there is one remaining estimation issue that requires our attention. The estimation of (3) may potentially be further complicated by interdependence between years of ownership and the effective tax rate. Recall the work of Wasi and White (2005), which indicated that assessment growth caps in California increased length of tenure in a home, relative to homeowners in states with no assessment growth cap. Thus, causality may run both ways. On the one hand, as long as home values are rising faster than the rate of inflation, effective tax rates fall every year a homeowner lives in the same home. On the other hand, the taxable value cap provides an incentive for homeowners to remain in their current home. This could potentially lead to a bias in the coefficient estimate on the years of homeownership.

${ }^{30}$ Detroit's population is less than half as large as it was in the $1950 \mathrm{~s}$, but the city still has a large infrastructure to maintain. Because of these and other factors, statutory tax rates in Detroit are exceptionally high. According to the Michigan State Tax Commission, in 2008 the average statutory property tax rate in Detroit was 68.18 mills, whereas the statewide average rate was 38.94 mills.

${ }^{31}$ URBAN was defined by identifying the community of residence for each survey respondent, and then using the Census Bureau's definition of an urbanized area to classify each community. (The precise definition is provided in Appendix A.) In Michigan, cities have greater taxing authority and provide a greater array of public services than do townships. It is important to note that, as defined by the Census Bureau, a community that is characterized as a city is not necessarily a part of an urbanized area. Thus, a city can be located in either an urbanized area or a rural area. Similarly, townships can be either urban or rural. 
To examine the possible endogeneity of years of ownership, we conduct a test of endogeneity, based on the techniques developed by Hausman $(1978,1983)$. The Hausman test requires that we identify at least one variable that determines length of homeownership, but does not directly determine effective tax rates. We identified $B L A C K$ and EDUCATION as potential instruments. In column (2) of Appendix C, we report a regression in which the variable CONSECUTIVE YEARS SINCE A is regressed on homeowner economic and demographic characteristics. Recall that CONSECUTIVE YEARS SINCE $A$ is capped at 13 years, because the assessment growth cap was implemented in 1994; thus, in 2007, there was no additional gain from having owned a home for more than 13 years. While BLACK is a significant determinant of CONSECUTIVE YEARS (column (1) of Appendix C), unfortunately neither BLACK nor EDUCATION is close to statistical significance in the regression for CONSECUTIVE YEARS SINCE $A$. Therefore, BLACK and EDUCATION are not good instruments, and we are not able to examine the endogeneity issue formally. Nevertheless, we believe that our examination of the relationship between CONSECUTIVE YEARS and effective tax rates is useful, in the sense that we use it to link effective tax rates with the economic and demographic characteristics of homeowners. In a further attempt to explore the endogeneity issue, we replaced CONSECUTIVE YEARS SINCE A with the non-capped variable CONSECUTIVE YEARS, and then conducted a Hausman test of endogeneity. We did not find evidence of an endogenous relationship between effective tax rates and CONSECUTIVE YEARS. This lends some credibility to the notion that we are measuring a causal relationship between CONSECUTIVE YEARS SINCE A and effective tax rates. ${ }^{32}$ We now turn our attention to the regression results.

\section{EMPIRICAL ANALYSIS}

The first set of estimation results is presented in Table 3. In this table, columns (1) and (2) contain the OLS estimates, and columns (3) and (4) contain the second-stage outcome estimates, corrected for selection bias. The results presented in columns (1) and (3) are from equations that do not distinguish between communities on the basis of their population growth rates. However, communities in Michigan had substantial variation in their rates of population growth during the period under study. These differences could be expected to be associated with different degrees of appreciation in property values. Therefore, in columns (2) and (4) of Table 3, we present results in which the variable for years of ownership is interacted with indicator variables for low, medium, and high rates of population growth. We focus our discussion on the OLS estimates, since the estimates based on the Heckman correction for sample selection are very similar to the OLS estimates in most cases.

${ }^{32}$ Even if we are only capturing correlations, our analysis succeeds in achieving a more modest objective, in that we measure the differences in effective tax rates for (1) homeowners who have lived in the same home for varying lengths of time, and (2) homeowners with different demographic characteristics. These results are interesting, even if they are simply viewed as correlations. We thank an anonymous referee for pointing out the value of this analysis of whether the relationships examined are viewed as causal. 


\begin{tabular}{|c|c|c|c|c|}
\hline \multicolumn{5}{|c|}{$\begin{array}{c}\text { Table } 3 \\
\text { OLS and Heckman Effective Tax Rate Regression Results } \\
\text { (t-statistics or } z \text {-statistics in parentheses })\end{array}$} \\
\hline \multirow[b]{3}{*}{ Independent Variable } & \multicolumn{4}{|c|}{ Dependent Variable: EFFECTIVE RATE } \\
\hline & \multicolumn{2}{|c|}{ OLS } & \multicolumn{2}{|c|}{ Heckman } \\
\hline & (1) & $(2)$ & (3) & (4) \\
\hline $\operatorname{Ln}(P O P U L A T I O N)$ & $\begin{array}{l}1.049^{*} \\
(1.83)\end{array}$ & $\begin{array}{l}1.027^{*} \\
(1.80)\end{array}$ & $\begin{array}{l}1.010^{*} \\
(1.74)\end{array}$ & $\begin{array}{l}0.994 * \\
(1.72)\end{array}$ \\
\hline $\operatorname{Ln}(W E A L T H)$ & $\begin{array}{l}0.738 \\
(0.57)\end{array}$ & $\begin{array}{l}1.243 \\
(0.96)\end{array}$ & $\begin{array}{l}0.864 \\
(0.67)\end{array}$ & $\begin{array}{l}1.373 \\
(1.06)\end{array}$ \\
\hline MOBILE HOME & $\begin{array}{c}-28.94 * * * \\
(-20.95)\end{array}$ & $\begin{array}{c}-28.83 * * * \\
(-20.90)\end{array}$ & $\begin{array}{c}-28.95 * * * \\
(-20.70)\end{array}$ & $\begin{array}{c}-28.83 * * * \\
(-20.70)\end{array}$ \\
\hline DETROIT & $\begin{array}{l}1.784 \\
(0.42)\end{array}$ & $\begin{array}{l}1.346 \\
(0.31)\end{array}$ & $\begin{array}{l}2.078 \\
(0.48)\end{array}$ & $\begin{array}{l}1.581 \\
(0.36)\end{array}$ \\
\hline$U R B A N C I T Y$ & $\begin{array}{c}6.670 * * * \\
(3.42)\end{array}$ & $\begin{array}{c}6.404 * * * \\
(3.37)\end{array}$ & $\begin{array}{c}6.906^{* * *} \\
(3.49)\end{array}$ & $\begin{array}{l}6.594 * * * \\
(3.43)\end{array}$ \\
\hline URBAN TOWNSHIP & $\begin{array}{l}2.181 \\
(0.86)\end{array}$ & $\begin{array}{l}2.445 \\
(0.95)\end{array}$ & $\begin{array}{l}2.451 \\
(0.95)\end{array}$ & $\begin{array}{l}2.700 \\
(1.03)\end{array}$ \\
\hline RURAL CITY & $\begin{array}{c}3.935 * * \\
(2.08)\end{array}$ & $\begin{array}{c}3.996 * * \\
(2.11)\end{array}$ & $\begin{array}{c}4.095 * * \\
(2.12)\end{array}$ & $\begin{array}{c}4.144 * * \\
(2.14)\end{array}$ \\
\hline $\begin{array}{l}\text { CONSECUTIVE YEARS } \\
\text { SINCE A }\end{array}$ & $\begin{array}{c}-0.394 * * \\
(-2.31)\end{array}$ & & $\begin{array}{c}-0.414 * * \\
(-2.39)\end{array}$ & \\
\hline $\begin{array}{l}\text { CONSECUTIVE YEARS } \\
\text { SINCE A } x \text { SLOW GROWTH }\end{array}$ & & $\begin{array}{l}-0.293 \\
(-1.56)\end{array}$ & & $\begin{array}{l}-0.306 \\
(-1.61)\end{array}$ \\
\hline $\begin{array}{l}\text { CONSECUTIVE YEARS } \\
\text { SINCE A } \times \text { MEDIUM GROWTH }\end{array}$ & & $\begin{array}{c}-0.478 * * * \\
(-2.75)\end{array}$ & & $\begin{array}{c}-0.499 * * * \\
(-2.82)\end{array}$ \\
\hline $\begin{array}{l}\text { CONSECUTIVE YEARS } \\
\text { SINCE A } \times \text { HIGH GROWTH }\end{array}$ & & $\begin{array}{c}-0.478^{* *} \\
(-2.31)\end{array}$ & & $\begin{array}{c}-0.496 * * \\
(-2.36)\end{array}$ \\
\hline R-squared & 0.287 & 0.292 & & \\
\hline Rho & & & -0.106 & -0.092 \\
\hline Number of Observations & 443 & 443 & 628 & 628 \\
\hline Censored & & & 185 & 185 \\
\hline Uncensored & & & 443 & 443 \\
\hline
\end{tabular}


First, we consider the results for the control variables. The coefficients on POPULA$T I O N$ are positive and statistically significant: All else equal, communities with larger populations have higher effective property tax rates. Also, the variable indicating whether a participant lives in a mobile-home park is highly significant and negative. This is to be expected, since Michigan residents who live in a mobile-home park pay no property taxes on their mobile home.

The coefficients on the URBAN CITY indicator variable are also significant, indicating that those living in urban-area cities pay higher effective rates of property tax, all else equal, when compared with the excluded category of rural townships. The coefficient estimates indicate that urban city dwellers pay approximately 6.7 mills more than those who reside in rural townships, all else equal. Residents of rural cities pay about 3.9 mills more than those living in rural townships, all else equal, and this relationship is also statistically significant. However, residents of urban townships only pay about 2.2 mills more than those living in rural townships, and this difference is not statistically significant. These results are not unexpected, since cities often provide more services and have greater taxing authority than do townships. Further, many cities in Michigan have experienced population decline. Thus, the costs of maintaining infrastructure and providing services over the same geographic area is spread over fewer households, and this has exerted upward pressure on tax rates in a number of Michigan cities. ${ }^{33}$

We have noted that the property tax rates in the city of Detroit are exceptionally high. However, after controlling for other factors (such as POPULATION and the trio of indicator variables, URBAN CITY, URBAN TOWNSHIP, AND RURAL CITY), the coefficients on the DETROIT indicator variable are insignificant.

The coefficient on WEALTH falls well short of statistical significance. On the one hand, all else equal, we might expect individuals who live in communities with greater per-capita wealth to have lower property tax rates, because a larger tax base can generate a given amount of tax revenue with a lower tax rate. On the other hand, the residents of affluent communities may have strong preferences for some of the public goods that are financed with property taxes. The insignificant coefficient for WEALTH suggests that these two influences may roughly offset each other.

Next, we turn to the effect of CONSECUTIVE YEARS SINCE $A$ on effective tax rates, the estimates for which are shown in columns (1) and (3) of Table 3. All else equal, effective property tax rates are reduced significantly as the number of years of ownership increases. This result is consistent with the result of Mikesell and Mullins (2008), who find that tenure in the home is negatively correlated with the percentage of income that goes to property tax payments.

${ }^{33}$ Michigan has 275 cities and 1242 townships. From 1990 to 2000, population in Michigan townships grew by 16.9 percent, whereas the population in cities actually declined by 1.2 percent. A number of larger Michigan cities experienced significant declines in population. These include Bay City (with a decrease of 5.4 percent), Detroit (7.5 percent), East Lansing (8.3 percent), Flint (11.2 percent), Lansing (6.8 percent), Saginaw (11.1 percent), Southgate ( 2.1 percent), and Traverse City ( 4.8 percent). 
Specifically, the estimates in column (1) of Table 3 show that homeowners' effective property tax rates are reduced by about 0.39 mills for every year of ownership, relative to a new homeowner, all else equal. (This is a reduction of approximately 1.43 percent per year.) Thus, homeowners who have lived in their home since 1994 (or earlier) face an effective property tax rate that is about 19 percent less than the effective rate faced by new homebuyers, all else equal.

The tax benefits for long-time homeowners in communities with different growth rates can be seen in columns (2) and (4) of Table 3 . These results indicate that long-time homeowners in areas with slow population growth experience a much smaller reduction in effective property tax rates than do those in areas with more rapid population growth. The tax rate reductions for long-time homeowners in slow-growth areas are relatively small, and the coefficients are less precisely estimated. However, the tax rate reductions in areas with medium and high rates of population growth are statistically significant. For areas with medium and high rates of population growth, the estimates indicate that homeowners' effective tax rates are reduced by about 0.48 mills for every year of ownership. This is a reduction of about 1.8 percent per year, accruing to annual savings of 23 percent for long-time homeowners relative to new homeowners.

In Table 3, we have seen that the length of homeownership plays an important role in determining effective property tax rates. Beyond that, however, we would also like to know which variables have an influence on the length of homeownership. Appendix $\mathrm{C}$ contains the results of regressions examining the relationship between the length of tenure in a home and the specific socioeconomic characteristics of homeowners. In column (1) of Appendix C, the dependent variable is CONSECUTIVE YEARS (years not capped at 13 years), while the dependent variable in column (2) is CONSECUTIVE YEARS SINCE A (years capped at 13 years) ${ }^{34}$ In both columns, we see that the number of years of ownership is not systematically related to living in urban cities, urban townships, rural cities, or rural townships, all else equal. Both columns also reveal that those who live in mobile homes have significantly shorter tenure. However, the results in the two columns differ in some respects. The coefficient on $B L A C K$ is significant in column (1) of Appendix C, but insignificant in column (2).$^{35}$ The coefficient on $A G E$ is statistically significant in each of the columns, but its magnitude is much smaller in column (2).

The findings in Appendix $C$ provide the basis for our next set of regressions, reported in Table 4. In these regressions, we replace CONSECUTIVE YEARS SINCE A with socioeconomic characteristics, to map the relationship between effective property tax rates and homeowner characteristics. Thus, Table 4 is similar to Table 3 ; the difference is that the number of years of homeownership is not used as an explanatory variable

\footnotetext{
${ }^{34}$ Approximately half of the homeowners in the survey have owned their home at least since the passage of Proposal A in 1994.

${ }^{35}$ In our sample, the average number of years of homeownership for African Americans is significantly less than for the general population (although homeownership rates for African Americans have increased in recent years). The insignificance of BLACK in the CONSECUTIVE YEARS SINCE A regression may be the result of the reduction in differences in homeownership rates across demographic groups in recent years, combined with capping the length of homeownership at 13 years.
} 


\begin{tabular}{|c|c|c|c|c|}
\hline \multicolumn{5}{|c|}{$\begin{array}{c}\text { Table } 4 \\
\text { OLS and Heckman Effective Tax Rate Regression Results } \\
\text { (t-statistics and } z \text {-statistics in parentheses })\end{array}$} \\
\hline \multirow[b]{3}{*}{ Independent Variable } & \multicolumn{4}{|c|}{ Dependent Variable: EFFECTIVE RATE } \\
\hline & \multicolumn{2}{|c|}{ OLS } & \multicolumn{2}{|c|}{ Heckman } \\
\hline & $(1)$ & $(2)$ & $(3)$ & (4) \\
\hline $\operatorname{Ln}(P O P U L A T I O N)$ & $\begin{array}{c}1.102 * \\
(1.93)\end{array}$ & $\begin{array}{c}1.095^{*} \\
(1.93)\end{array}$ & $\begin{array}{c}1.078^{*} \\
(1.86)\end{array}$ & $\begin{array}{c}1.068^{*} \\
(1.86)\end{array}$ \\
\hline $\operatorname{Ln}(W E A L T H)$ & $\begin{array}{l}0.627 \\
(0.50)\end{array}$ & $\begin{array}{l}0.672 \\
(0.53)\end{array}$ & $\begin{array}{l}0.799 \\
(0.64)\end{array}$ & $\begin{array}{l}0.890 \\
(0.69)\end{array}$ \\
\hline MOBILE HOME & $\begin{array}{c}-28.27 * * * \\
(-18.70)\end{array}$ & $\begin{array}{c}-27.99 * * * \\
(-21.24)\end{array}$ & $\begin{array}{c}-28.37 * * * \\
(-18.35)\end{array}$ & $\begin{array}{c}-28.08 * * * \\
(-20.75)\end{array}$ \\
\hline DETROIT & $\begin{array}{l}1.857 \\
(0.44)\end{array}$ & $\begin{array}{l}2.216 \\
(0.53)\end{array}$ & $\begin{array}{l}2.156 \\
(0.51)\end{array}$ & $\begin{array}{l}2.567 \\
(0.61)\end{array}$ \\
\hline URBAN CITY & $\begin{array}{c}6.299 * * * \\
(3.27)\end{array}$ & $\begin{array}{c}6.159 * * * \\
(3.22)\end{array}$ & $\begin{array}{c}6.517 * * * \\
(3.34)\end{array}$ & $\begin{array}{c}6.423 * * * \\
(3.30)\end{array}$ \\
\hline URBAN TOWNSHIP & $\begin{array}{l}1.469 \\
(0.61)\end{array}$ & $\begin{array}{l}1.442 \\
(0.59)\end{array}$ & $\begin{array}{l}1.699 \\
(0.70)\end{array}$ & $\begin{array}{l}1.716 \\
(0.69)\end{array}$ \\
\hline RURAL CITY & $\begin{array}{c}3.807 * * \\
(2.12)\end{array}$ & $\begin{array}{c}3.652^{* *} \\
(1.97)\end{array}$ & $\begin{array}{c}3.961 * * \\
(2.16)\end{array}$ & $\begin{array}{c}3.850 * * \\
(2.03)\end{array}$ \\
\hline $20 k<I N C O M E<40 k$ & $\begin{array}{c}-7.146^{* *} \\
(-2.27)\end{array}$ & & $\begin{array}{c}-6.918 * * \\
(-2.25)\end{array}$ & \\
\hline $40 k<I N C O M E<70 k$ & $\begin{array}{l}-3.530 \\
(-1.12)\end{array}$ & & $\begin{array}{l}-3.565 \\
(-1.13)\end{array}$ & \\
\hline INCOME $>70 k$ & $\begin{array}{c}-6.471 * * \\
(-1.98)\end{array}$ & & $\begin{array}{c}-6.658^{* *} \\
(-2.00)\end{array}$ & \\
\hline$A G E$ & $\begin{array}{l}-0.035 \\
(-0.61)\end{array}$ & $\begin{array}{l}0.028 \\
(0.49)\end{array}$ & $\begin{array}{l}-0.046 \\
(-0.76)\end{array}$ & $\begin{array}{l}0.017 \\
(0.28)\end{array}$ \\
\hline$A G E \times(20 k<I N C O M E<40 k)$ & & $\begin{array}{c}-0.103 * * \\
(-2.39)\end{array}$ & & $\begin{array}{c}-0.100 * * \\
(-2.34)\end{array}$ \\
\hline$A G E x(40 k<I N C O M E<70 k)$ & & $\begin{array}{l}-0.041 \\
(-0.94)\end{array}$ & & $\begin{array}{l}-0.043 \\
(-0.97)\end{array}$ \\
\hline$A G E x(I N C O M E>70 k)$ & & $\begin{array}{c}-0.098 * * \\
(-2.04)\end{array}$ & & $\begin{array}{c}-0.101 * * \\
(-2.09)\end{array}$ \\
\hline R-squared & 0.298 & 0.294 & & \\
\hline Rho & & & -0.099 & -0.119 \\
\hline $\begin{array}{l}\text { Number of Observations } \\
\text { Censored } \\
\text { Uncensored }\end{array}$ & 443 & 443 & $\begin{array}{l}628 \\
185 \\
443\end{array}$ & $\begin{array}{l}628 \\
185 \\
443\end{array}$ \\
\hline
\end{tabular}


in Table 4. ${ }^{36}$ In Table 4, we also introduce several categories of household income as explanatory variables. (The excluded category consists of homeowners with annual incomes below $\$ 20,000$.)

The coefficients on the income indicator variables are negative, and are statistically significant for the $\$ 20,000-\$ 40,000$ and the over- $\$ 70,000$ income categories. These negative coefficients indicate that, holding other factors constant, effective property tax rates are lower for these income classes, when compared to those with incomes below $\$ 20,000$. These results indicate that, all else equal, those with higher incomes have lower effective tax rates, although the relationship is nonlinear. Although we cannot be sure that the taxable value cap is the cause of the negative coefficient on income, these results are consistent with the idea that the taxable value cap may have caused the property tax to be more regressive, or less progressive, than it otherwise would have been.

In light of the estimates presented in Appendix $\mathrm{C}$, we had expected a strong relationship between $A G E$ and effective tax rates. However, columns (1) and (3) of Table 4 indicate that, although the coefficients on $A G E$ are of the expected negative sign, they are not statistically significant. To explore age-income effects further, we report additional estimates in columns (2) and (4) of Table 4. In these columns, we report on regressions in which the three income categories are replaced by variables in which the three income-indicator variables are interacted with $A G E$. In these regressions, the coefficients on $A G E \mathrm{x}(20 k<I N C O M E<40 k)$ and $A G E \mathrm{x}(I N C O M E>70 k)$ are negative and statistically significant. This indicates that, all else equal, older homeowners in these income categories have lower effective tax rates, relative to younger homeowners in these income categories. Within these two income groups, the estimates indicate that a 63 -year-old homeowner enjoys a reduction of about 11 percent in the effective property tax rate, compared with a 23 -year-old homeowner. ${ }^{37}$ These results reveal that within at least two income classes, $A G E$ is a significant determinant of effective tax rates. Taken together, these results provide evidence that older and middle- to high-income homeowners appear to have benefited most from the taxable value cap, at the expense of younger and low-income homeowners. ${ }^{38}$

We also estimated a number of other alternative specifications, to examine the robustness of our findings. As noted earlier, Michigan has a Homestead Property Tax Credit

\footnotetext{
${ }^{36}$ Note that the regressions shown in Tables 3 and 4 do not include $B L A C K$ or EDUCATION as regressors. We explicitly excluded $E D U C A T I O N$ from the reported effective-tax-rate regressions, because we use this variable as an instrument in the selection equation. In other regressions (not reported here), we included $B L A C K, E D U C A T I O N$, and other demographic characteristics, but none of these other variables was a statistically significant determinant of home tenure. These estimates are available upon request from the authors. Also note that using additional variables (such as $B L A C K$ ) as instruments in the selection regression yields similar results.

${ }^{37}$ To calculate this result, we add the coefficients on $A G E$ and $A G E \mathrm{x}(20 k<I N C O M E<40 k)$ or $A G E \mathrm{x}(I N C O M E$ $>70 k)$, multiply by $(63-23)=40$ years, and then divide by the average effective tax rate (27.24).

${ }^{38}$ These findings are consistent with U.S. Census Bureau data on migration patterns, which show that mobility peaks between the ages of 18 and 30 and then generally decreases until very late in life (U.S. Census Bureau, 2003).
} 
embedded in its income tax code, and this serves to reduce the burden of property taxes for lower income households. To determine whether our core results are robust to an alternative definition of property tax burden that nets out this credit, we used survey data on household income, age, and the size of the property tax payment, along with detailed information from the Michigan Department of Treasury regarding the credit, to estimate the size of the credit for all those who qualified. ${ }^{39}$ We then created an "Adjusted Effective Property Tax Rate" by subtracting the property tax credit from the overall property tax payment, and then dividing by state equalized value. We then used this measure of tax burden to study the implications of the taxable value cap. These estimates (which are available from the authors upon request) are similar to those presented in this study.

Recall that 37 respondents were excluded from the analysis because they provided inconsistent information about age and homeownership. For example, a respondent may have indicated that he/she is 30 years of age, and that he/she had owned the home for 20 years. This person would therefore have become a homeowner at the age of 10 , which seems highly unrealistic. However, it is conceivable that person has lived in the home for 20 years, and is now a joint title holder with an older parent of the property. In this case, the survey respondent may very well be receiving a tax benefit, and omitting these observations might bias our results. To examine this issue, we ran a series of regressions in which these observations were included in the sample; the results are again consistent with our core estimates, but the size of the coefficient on CONSECUTIVE YEARS SINCE A is roughly 30 percent larger. The regressions we present are thus the more conservative of the estimates.

In Michigan, 21 cities have an income tax, and this may affect the property tax burden for the residents of those cities. We therefore estimated regressions in which we included either (1) a variable that indicates whether city uses an income tax, or (2) a variable that measures actual income tax rates. ${ }^{40}$ These regressions are again very similar to those presented, and the coefficients on the income tax variables are never statistically significant.

We also estimated regressions in which the actual tax payment (instead of the EFFECTIVE TAX RATE variable) is used as the dependent variable. ${ }^{41}$ These results indicate somewhat larger effects of CONSECUTIVE YEARS SINCE A and the age-income interaction variables than those presented in this article. Finally, we estimated a linear (as opposed to log-linear) specification, and again those estimates are very similar to those presented.

${ }^{39}$ In our sample, we estimate that 272 of 443 respondents qualify for the tax credit. The average value of the credit was $\$ 669$. We subtracted this value from the reported property tax payment, and then divided this adjusted tax payment by state equalized value, to obtain the "Adjusted Effective Property Tax Rate." We recommend some caution in interpreting these results, however, since we are unable to verify whether a respondent actually claimed the Homestead Property Tax Credit.

${ }^{40}$ Income taxes are levied in the following Michigan cities: Albion, Battle Creek, Big Rapids, Detroit, Flint, Grand Rapids, Grayling, Hamtramck, Highland Park, Hudson, Ionia, Jackson, Lansing, Lapeer, Muskegon, Muskegon Heights, Pontiac, Port Huron, Portland, Saginaw, Springfield, and Walker. However, no residents of Albion, Hamtramck, Highland Park, Hudson, Lapeer, Muskegon Heights, Pontiac, Portland, or Springfield are represented in our sample.

${ }^{41}$ The value of the home is included as an explanatory variable on the right-hand side in these regressions. 


\section{CONCLUSIONS}

In this article, we evaluate the distributional consequences of the taxable value cap in the property tax in Michigan. We demonstrate the link between the taxable value cap and a substantial redistribution of property tax payments. We find that the length of tenure in a home is negatively correlated with the homeowner's effective rate of property tax. Specifically, our estimates indicate that homeowners who have lived in their home since 1994 (or earlier) face an effective property tax rate that is about 19 percent less than the effective rate faced by new homebuyers, all else equal, and the effect increases to 23 percent in high growth areas. Thus, the taxable value cap leads to a redistribution of effective property tax payments, with lower tax payments for long-time residents, and higher tax payments for relative newcomers. We also find that within the lower-middle and high income groups, older homeowners enjoy a tax benefit over younger homeowners, on average. Our estimates indicate that, all else equal, a 63-year-old homeowner receives a tax saving of about 11 percent relative to a 23 -year-old homeowner.

We also document a regressive relationship between income and effective tax rates: All else equal, middle- to high-income homeowners have lower effective property tax rates, relative to low-income homeowners. In fact, nearly all of the tax features of Proposal A were regressive. In addition to the taxable value cap, Proposal A reduced property taxes overall, and raised cigarette taxes. Also, when Proposal A was passed, voters were given a choice. Each of the two choices involved reductions in property taxes, but the two choices differed in the method of making up the lost tax revenue. Voters could have chosen higher income taxes, but they chose higher sales taxes instead.

Thus, on the revenue side, Proposal A was nearly uniformly regressive. On the expenditure side, however, Proposal A was undoubtedly progressive, in the sense that it provided disproportionate benefits to low-wealth school districts (Papke, 2005). This combination of regressive taxes and progressive spending is not unique to Michigan. Many European countries finance large public expenditures that are favorable to lowand middle-income residents, partly by relying on the revenue-raising power of a regressive value-added tax.

Home values have fallen across Michigan over the past few years. As mentioned earlier, this has meant that some long-time homeowners have experienced increasing property taxes and falling home values at the same time. This has led to considerable controversy, and a number of legislative proposals have been put forth to deal with the issue. One proposal would prevent taxable values (and thus tax payments) from rising in the face of falling home values. This proposal, which has received some support in the state legislature, would preserve the horizontal inequities resulting from the taxable value cap.

Our analysis suggests that it might be better to consider repeal of the taxable value cap. Holding revenues constant, repeal of the taxable value cap would result in a broadening of the tax base, which would make it possible to raise the same amount of revenue with lower statutory tax rates. ${ }^{42}$ Furthermore, repeal of the taxable value cap would avoid

\footnotetext{
${ }^{42}$ The potential reduction in statutory rates would depend on the trajectory of housing prices.
} 
the potential distortions that could be created by future housing price increases. Haveman and Sexton (2008) recommend alternative property tax relief measures, such as circuit-breaker programs, partial exemptions on owner-occupied housing, and property tax deferral options. Each of these alternative tax-relief measures is already in place in Michigan, in one form or another. If the taxable value cap were to be removed, these other provisions of Michigan law, along with the Headlee tax-revenue growth limit, could provide adequate checks against excessive growth of property tax revenues.

Finally, we acknowledge that our analysis offers a snapshot of effective tax rates at a single point in time. Although some of our regressions include age and income as explanatory variables, we do not claim that ours is a complete analysis of the life-cycle effects of property taxes. Economists have shown the value of tax-incidence analyses that trace the changes in tax burdens over the life cycle (Davies, St.-Hilaire, and Whalley, 1984; Fullerton and Rogers, 1993). It would be interesting to embed our results in a life-cycle framework.

\section{ACKNOWLEDGEMENTS}

We are grateful to Larry Hembroff and Karen Clark for their excellent work on the public opinion survey that forms part of the basis for this article. We also thank George Zodrow and two anonymous referees for helpful comments on an earlier version of the article. Any errors are our responsibility.

\section{REFERENCES}

Achen, Christopher H., 1986. The Statistical Analysis of Quasi-Experiments. University of California Press, Berkeley, CA.

Anderson, Nathan B., and Therese J. McGuire, 2007. "An Unfettered Property Tax in Illinois." Working Paper WP07NA2. Lincoln Institute of Land Policy, Cambridge, MA.

Arsen, David, and David N. Plank, 2003. "Michigan School Finance under Proposal A: State Control, Local Consequences." Working Paper. The Education Policy Center at Michigan State University, East Lansing, MI.

Arsen, David, Tom Clay, Thomas Davis, Thomas Devaney, Rachel Fulcher-Dawson, and David N. Plank, 2005. "Adequacy, Equity, and Capital Spending in Michigan Schools: The Unfinished Business of Proposal A." Citizens Research Council of Michigan and the Education Policy Center at Michigan State University Center, East Lansing, MI, http://www.crcmich.org/ PUBLICAT/2000s/2005/schoolcapital.pdf.

Bowman, John H., 2006. "Property Tax Policy Responses to Rapidly Rising Home Values: District of Columbia, Maryland, and Virginia." National Tax Journal 59 (3), 717-733.

Davies, James, France St.-Hilaire, and John Whalley, 1984. "Some Calculations of Lifetime Tax Incidence." American Economic Review 74 (4), 633-649. 
Dye, Richard F., Therese J. McGuire, and Daniel P. McMillen, 2005. “Are Property Tax Limitations More Binding Over Time?” National Tax Journal 58 (2), 215-225.

Dye, Richard F., Daniel P. McMillen, and David F. Merriman, 2006. "Illinois' Response to Rising Residential Property Values: An Assessment Growth Cap in Cook County." National Tax Journal 59 (3), 707-716.

Feldman, Naomi E., Paul N. Courant, and Douglas C. Drake, 2003. "The Property Tax in Michigan." In Ballard, Charles L., Paul N. Courant, Douglas C. Drake, Ronald C. Fisher, and Elisabeth R. Gerber (eds.), Michigan at the Millennium, 577-602. Michigan State University Press, East Lansing, MI.

Ferreira, Fernando, 2004. "You Can Take It with You: Transferability of Proposition 13 Tax Benefits, Residential Mobility, and Willingness to Pay for Housing Amenities." Working Paper 72. Center for Labor Economics, University of California, Berkeley, CA.

Fullerton, Don, and Diane Lim Rogers, 1993. Who Bears the Lifetime Tax Burden? The Brookings Institution, Washington, DC.

Giertz, J. Fred, 2006. “The Property Tax Bound.” National Tax Journal 59 (3), 695-705.

Guilfoyle, Jeffrey P., 1998. “The Incidence and Housing Market Effects of Michigan's 1994 School Finance Reforms.” Ph.D. Dissertation. Michigan State University, East Lansing, MI.

Hausman, Jerry A., 1978. “Specification Tests in Econometrics.” Econometrica 46 (6), 1251-1271.

Hausman, Jerry A., 1983. "Specification and Estimation of Simultaneous Equations Models.” In Griliches, Zvi, and Michael D. Intriligator (eds.), Handbook of Econometrics, Volume I, 391-448. North Holland, Amsterdam, The Netherlands.

Haveman, Mark, and Terri Sexton, 2008. "Property Tax Assessment Limits: Lessons from Thirty Years of Experience." Focus Report, Lincoln Institute of Land Policy, Cambridge, MA, http:// www.lincolninst.edu/pubs/PubDetail.aspx?pubid=1412.

Heckman, James J., 1979. "Sample Selection Bias as a Specification Error.” Econometrica 47 (1), 153-161.

Ihlanfeldt, Keith, forthcoming. "Do Caps on Increases in Assessed Values Create a Lock-in Effect? Evidence from Florida's Amendment One.” National Tax Journal.

King, A. Thomas, 1977. "Estimating Property Tax Capitalization: A Critical Comment.” Journal of Political Economy 85 (2), 425-431.

Michigan Department of Treasury, 2010. "Executive Budget Appendix on Tax Credits, Deductions, and Exemptions, Fiscal Year 2010.” Michigan Department of Treasury, Lansing, MI, http://www. michigan.gov/documents/treasury/ExecBudgAppenTaxCreditsDedExemptsFY10_302899_7.pdf.

Mikesell, John, and Daniel Mullins, 2008. "The Effects of Property Tax Systems on Household Property Tax Burdens.” State Tax Notes 47 (7), 533-545. 
Minnesota Department of Revenue, 2007. Limited Market Value Report: 2006 Assessment Year. Minnesota Department of Revenue, St. Paul, MN, www.taxes.state.mn.us/taxes/legal_policy/ research_reports/content/2007_lmv_report.pdf.

Muhammad, Daniel, 2007. "Horizontal Inequity, Vertical Inequity and the District of Columbia's Property Assessment Limitation.” Paper presented at the National Tax Association's $100^{\text {th }}$ Annual Conference on Taxation, November 15. Columbus, $\mathrm{OH}$.

Mullins, Daniel R., and Philip G. Joyce, 1996. "Tax and Expenditure Limitations and State and Local Fiscal Structure: An Empirical Analysis." Public Budgeting and Finance 16 (1), 75-101.

Nagy, John, 1997. "Did Proposition 13 Affect the Mobility of California Homeowners?" Public Finance Review 25 (1), 102-116.

Oates, Wallace E., 1969. "The Effects of Property Taxes and Local Public Spending on Property Values: An Empirical Study of Tax Capitalization and the Tiebout Hypothesis." Journal of Political Economy 77 (6), 957-971.

Palmon, Oded, and Barton A. Smith, 1998. "Confirmation and Contradictions: New Evidence on Property Tax Capitalization.” Journal of Political Economy 106 (5), 1099-1111.

Papke, Leslie E., 2005. "The Effects of Spending on Test Pass Rates: Evidence from Michigan." Journal of Public Economics 89 (5), 821-839.

Papke, Leslie E., 2008. “The Effects of Changes in Michigan's School Finance System.” Public Finance Review 36 (4), 456-474.

Reinhard, Raymond M., 1981. "Estimating Property Tax Capitalization: A Further Comment." Journal of Political Economy 89 (6), 1251-1260.

Richardson, David H., and Richard Thalheimer, 1981. "Measuring the Extent of Property Tax Capitalization for Single Family Residences.” Southern Economic Journal 47 (3), 674-689.

Rosen, Kenneth T., 1982. "The Impact of Proposition 13 on House Prices in Northern California: A Test of the Interjurisdictional Capitalization Hypothesis." Journal of Political Economy 90 (1), 191-200.

Sigelman, Lee, and Langche Zeng, 1999. "Analyzing Censored and Sample-Selected Data with Tobit and Heckit Models." Political Analysis 8 (2), 167-182.

Skidmore, Mark, 1999. "Tax and Expenditure Limitations and the Fiscal Relationships between State and Local Governments." Public Choice 99 (1-2), 77-102.

United States Advisory Commission on Intergovernmental Relations, 1995. Tax and Expenditure Limitations on Local Governments. U.S. Government Printing Office, Washington, DC.

United States Bureau of the Census, 2003. Internal Migration of the Older Population: 1995 to 2000. Census 2000 Special Reports. United States Bureau of the Census, Washington, DC, http:// www.census.gov/prod/2003pubs/censr-10.pdf. 
Wales, T J., and Elmer G. Wiens, 1974. "Capitalization of Residential Property Taxes: An Empirical Study." Review of Economics and Statistics 56 (3), 329-333.

Wasi, Nada, and Michelle J. White, 2005. "Property Tax Limitations and Mobility: Lock-in Effect of California's Proposition 13.” In Burtless, Gary, and Janet Rothenberg Pack (eds.), BrookingsWharton Papers on Urban Affairs, Issue 6, 59-97. Brookings Institution, Washington, DC.

Yinger, John, 1982. "Capitalization and the Theory of Local Public Finance.” Journal of Political Economy 90 (5), 917-943.

Yinger, John, Howard S. Bloom, Axel Boersch-Supan, and Helen F. Ladd, 1988. Property Taxes and House Values: The Theory of Estimation of Intrajurisdictional Property Tax Capitalization. Academic Press, San Diego, CA.

Youngman, Joan M., 2007. "The Variety of Property Tax Limits: Goals, Consequences, and Alternatives." State Tax Notes 46 (8), 541-557. 


\section{APPENDIX A: DEFINITIONS OF VARIABLES}

\begin{tabular}{|c|c|}
\hline Variable & Definition \\
\hline EFFECTIVE RATE & $\begin{array}{l}\text { The effective property tax rate that respondents pay, measured } \\
\text { by the tax payment divided by the state equalized value of the } \\
\text { property. }\end{array}$ \\
\hline POPULATION & $\begin{array}{l}\text { The total population of the municipality or township in which } \\
\text { the respondent resides. }\end{array}$ \\
\hline WEALTH & $\begin{array}{l}\text { A measure of wealth of the municipality or township in which } \\
\text { the respondent lives, measured by the per-capita state equalized } \\
\text { value in the municipality/township. }\end{array}$ \\
\hline MOBILE HOME & $\begin{array}{l}\text { Indicator variable to distinguish whether a respondent lives in a } \\
\text { mobile home park ( } 1=\text { respondent lives in a mobile home park, } \\
\text { and } 0 \text { otherwise). Mobile-home park residents are exempt from } \\
\text { paying the property tax in Michigan. }\end{array}$ \\
\hline DETROIT & $\begin{array}{l}\text { Indicator variable to distinguish whether a respondent lives in } \\
\text { Detroit ( } 1=\text { if the respondent lives in Detroit, and } 0 \text { otherwise). }\end{array}$ \\
\hline$U R B A N$ & $\begin{array}{l}\text { Indicator variable to distinguish whether a respondent lives in an } \\
\text { urban area (vs. a non-urban area). Calculated by using the Cen- } \\
\text { sus Bureau's definition: an urban area has a core census block } \\
\text { with a population density of at least } 1,000 \text { people per square } \\
\text { mile, and has surrounding census blocks that have an overall } \\
\text { density of at least } 500 \text { people per square mile ( } 1=\text { if the respon- } \\
\text { dent lives in an urban setting, and } 0 \text { otherwise). }\end{array}$ \\
\hline CITY & $\begin{array}{l}\text { Indicator variable to distinguish whether a respondent lives in a } \\
\text { city ( } 1=\text { if the respondent lives in a city, and } 0 \text { otherwise). }\end{array}$ \\
\hline TOWNSHIP & $\begin{array}{l}\text { Indicator variable to distinguish whether a respondent lives } \\
\text { in a township ( } 1=\text { if the respondent lives in a township, and } 0 \\
\text { otherwise). }\end{array}$ \\
\hline $\begin{array}{l}\text { CONSECUTIVE } \\
\text { YEARS }\end{array}$ & $\begin{array}{l}\text { Number of consecutive years a respondent has lived in his/her } \\
\text { home. }\end{array}$ \\
\hline CONSECUTIVE & Number of consecutive years a respondent has lived in his/her \\
\hline$Y E A R S$ SINCE A & $\begin{array}{l}\text { home (maximum value }=13 \text { years). This maximum is in place } \\
\text { because Proposal A had been in effect for } 13 \text { years at the time of } \\
\text { the survey (since 1994). }\end{array}$ \\
\hline$B L A C K$ & $\begin{array}{l}\text { Indicator variable to distinguish whether the respondent is Afri- } \\
\text { can American ( } 1=\text { African American, and } 0 \text { otherwise). }\end{array}$ \\
\hline
\end{tabular}




\begin{tabular}{|c|c|}
\hline Variable & Definition \\
\hline EDUCATION & $\begin{array}{l}\text { Number of years a respondent was in school (e.g., high-school } \\
\text { graduate }=12 \text {, college graduate }=16) .\end{array}$ \\
\hline $20 k<I N C O M E<40 k$ & $\begin{array}{l}\text { Indicator variable to distinguish those individuals whose house- } \\
\text { hold income ranged from } \$ 20,000 \text { to } 40,000 \text { at the time of the } \\
\text { survey. }\end{array}$ \\
\hline $40 k<I N C O M E<70 k$ & $\begin{array}{l}\text { Indicator variable to distinguish those individuals whose house- } \\
\text { hold income ranged from } \$ 40,000 \text { to } 70,000 \text { at the time of the } \\
\text { survey. }\end{array}$ \\
\hline INCOME $>70 k$ & $\begin{array}{l}\text { Indicator variable to distinguish those individuals whose house- } \\
\text { hold income was above } \$ 70,000 \text { at the time of the survey. }\end{array}$ \\
\hline$A G E$ & Age of the respondent. \\
\hline MARRIED & $\begin{array}{l}\text { Indicator variable to distinguish whether the respondent is mar- } \\
\text { ried ( }=1 \text { if the person is married, }=0 \text { otherwise). }\end{array}$ \\
\hline SLOW GROWTH & $\begin{array}{l}\text { Indicator variable equal to } 1 \text { if the county in which the respon- } \\
\text { dent lives had an overall population growth rate less than } 5 \\
\text { percent between } 1994 \text { and 2006, and } 0 \text { otherwise. Twenty-nine } \\
\text { of Michigan's } 83 \text { counties were characterized as slow-growth } \\
\text { counties. }\end{array}$ \\
\hline MEDIUM GROWTH & $\begin{array}{l}\text { Indicator variable equal to } 1 \text { if the county in which the respon- } \\
\text { dent lives had a population growth rate between } 5 \text { percent and } \\
12 \text { percent, and } 0 \text { otherwise. Twenty-one of Michigan's } 83 \text { coun- } \\
\text { ties were characterized as medium-growth counties. }\end{array}$ \\
\hline HIGH GROWTH & $\begin{array}{l}\text { Indicator variable equal to } 1 \text { if the county in which the respon- } \\
\text { dent lives that had an overall population growth rate greater than } \\
12 \text { percent between } 1994 \text { and 2006, and } 0 \text { otherwise. Thirty- } \\
\text { three of Michigan's } 83 \text { counties were characterized as high- } \\
\text { growth counties. }\end{array}$ \\
\hline
\end{tabular}




\section{APPENDIX B: HECKMAN SELECTION EQUATION ESTIMATION RESULTS}

( $z$-statistics in parentheses)

\begin{tabular}{lc}
\hline Independent Variable & Dependent Variable: Selection Indicator Variable \\
\hline Ln $($ POPULATION $)$ & 0.068 \\
& $(0.96)$ \\
Ln $($ WEALTH $)$ & $-0.277^{*}$ \\
MOBILE HOME & $(-1.88)$ \\
& 0.091 \\
DETROIT & $(0.22)$ \\
& -0.535 \\
URBAN CITY & $(-1.60)$ \\
& $-0.457^{*}$ \\
URBAN TOWNSHIP & $(-1.95)$ \\
RURAL CITY & -0.480 \\
CONSECUTIVE YEARS SINCE A & $(-1.46)$ \\
EDUCATION & -0.311 \\
Rho & $(-1.49)$ \\
Number of Observations & $0.035^{* *}$ \\
Uncensored & $(2.26)$ \\
\hline
\end{tabular}

Notes: All regression results are corrected for selection bias and heteroskedasticity. Asterisks denote significance at the $5 \%(* *)$, and $10 \%(*)$ levels. 
APPENDIX C: LENGTH OF HOMEOWNERSHIP REGRESSION RESULTS

( $t$-statistics in parentheses)

\begin{tabular}{|c|c|c|}
\hline \multirow[b]{2}{*}{ Independent Variable } & \multicolumn{2}{|c|}{ Dependent Variable } \\
\hline & $\begin{array}{c}(1) \\
\text { CONSECUTIVE YEARS }\end{array}$ & $\begin{array}{c}(2) \\
\text { CONSECUTIVE YEARS SINCE A }\end{array}$ \\
\hline Ln (POPULATION) & $\begin{array}{l}0.177 \\
(0.31)\end{array}$ & $\begin{array}{l}-0.108 \\
(-0.50)\end{array}$ \\
\hline $\operatorname{Ln}(W E A L T H)$ & $\begin{array}{l}-1.529 \\
(-1.16)\end{array}$ & $\begin{array}{l}-0.063 \\
(-0.13)\end{array}$ \\
\hline MOBILE HOME & $\begin{array}{c}-6.386^{* * *} \\
(-2.62)\end{array}$ & $\begin{array}{c}-3.639 * * * \\
(-3.10)\end{array}$ \\
\hline DETROIT & $\begin{array}{l}4.132 \\
(1.04)\end{array}$ & $\begin{array}{l}0.227 \\
(0.12)\end{array}$ \\
\hline URBAN CITY & $\begin{array}{l}2.204 \\
(1.31)\end{array}$ & $\begin{array}{l}0.521 \\
(0.75)\end{array}$ \\
\hline URBAN TOWNSHIP & $\begin{array}{l}2.076 \\
(0.84)\end{array}$ & $\begin{array}{l}1.644^{*} \\
(1.77)\end{array}$ \\
\hline RURAL CITY & $\begin{array}{l}1.045 \\
(0.73)\end{array}$ & $\begin{array}{l}0.075 \\
(0.11)\end{array}$ \\
\hline$B L A C K$ & $\begin{array}{l}-6.243^{*} \\
(-1.77)\end{array}$ & $\begin{array}{l}-0.857 \\
(-0.52)\end{array}$ \\
\hline $20 k<I N C O M E<40 k$ & $\begin{array}{l}1.625 \\
(0.53)\end{array}$ & $\begin{array}{l}0.624 \\
(0.64)\end{array}$ \\
\hline $40 k<I N C O M E<70 k$ & $\begin{array}{l}2.512 \\
(0.89)\end{array}$ & $\begin{array}{l}0.466 \\
(0.46)\end{array}$ \\
\hline INCOME $>70 k$ & $\begin{array}{l}1.467 \\
(0.50)\end{array}$ & $\begin{array}{l}0.705 \\
(0.63)\end{array}$ \\
\hline$A G E$ & $\begin{array}{l}0.503 * * * \\
(9.45)\end{array}$ & $\begin{array}{l}0.121 * * * \\
(7.41)\end{array}$ \\
\hline MARRIED & $\begin{array}{l}1.068 \\
(0.68)\end{array}$ & $\begin{array}{l}0.756 \\
(1.44)\end{array}$ \\
\hline EDUCATION & $\begin{array}{l}-0.209 \\
(-0.76)\end{array}$ & $\begin{array}{l}-0.081 \\
(-0.72)\end{array}$ \\
\hline R-squared & 0.346 & 0.203 \\
\hline Number of Observations & 443 & 443 \\
\hline
\end{tabular}

Notes: All regression results are corrected for selection bias and heteroskedasticity. Asterisks denote significance at the $1 \%(* * *), 5 \%(* *)$, and $10 \%(*)$ levels. 
